\title{
TEKNIK PENANGKAPAN IKAN BELIDA (Notopterus chitala) MEMAKAI JARING INSANG PERMUKAAN DI SUNGAI KAMPAR BAGIAN HILIR, PROPINSI RIAU
}

\author{
Syamsul Bahri \\ Teknisi Litkayasa pada Balai Riset Perikanan Perairan Umum, Mariana-Palembang \\ Teregistrasi I tanggal: 14 Mei 2007; Diterima setelah perbaikan tanggal: 11 Juli 2007; \\ Disetujui terbit tanggal: 13 Agustus 2007
}

\section{PENDAHULUAN}

Ikan belida (Notopterus chitala) termasuk suku kecil ikan air tawar yang banyak terdapat di perairan Sungai Kampar bagian hilir, Propinsi Riau. Ikan ini dapat dikenali melalui sirip dubur yang sangat panjang, berawal tepat di belakang sirip perut, dihubungkan oleh sisik sisik kecil dengan sirip ekor. (Gambar 1).

Ikan belida bersifat predator, noktural -(hewan yang aktif mencari makan pada malam hari dan pada siang hari bersembunyi di antara vegetasi) dan dapat menghirup udara dari atmosfir (Kottelat et al., 1993). Daging ikan belida berharga mahal, tetapi karena banyak duri kurang disukai sebagai lauk pauk. Di Propinsi Sumatera Selatan (Palembang), daging ikan belida digunakan sebagai bahan untuk membuat produk olahan seperti kerupuk, kempelang, pempek, dan lain-lain.

Di tinjau dari aspek sumber daya alam, Sungai Kampar memiliki panjang 400 km dengan kedalaman rata-rata sekitar $6 \mathrm{~m}$, berhulu dari pegunungan bukit barisan (lubuk bangkul, Payakumbuh) Sumatera Barat dan bermuara di Selat Malaka (Tanjung Alai) (Anonimus, 2005) (Gambar 2). Sungai Kampar bagian hilir banyak ditemukan ikan belida. Apabila penangkapan ikan tersebut dilakukan tanpa memperhatikan kaidah-kaidah kelestarian, maka akan mengakibatkan penurunan stok atau kepunahan sumber daya perikanan khususnya ikan belida di daerah tersebut.

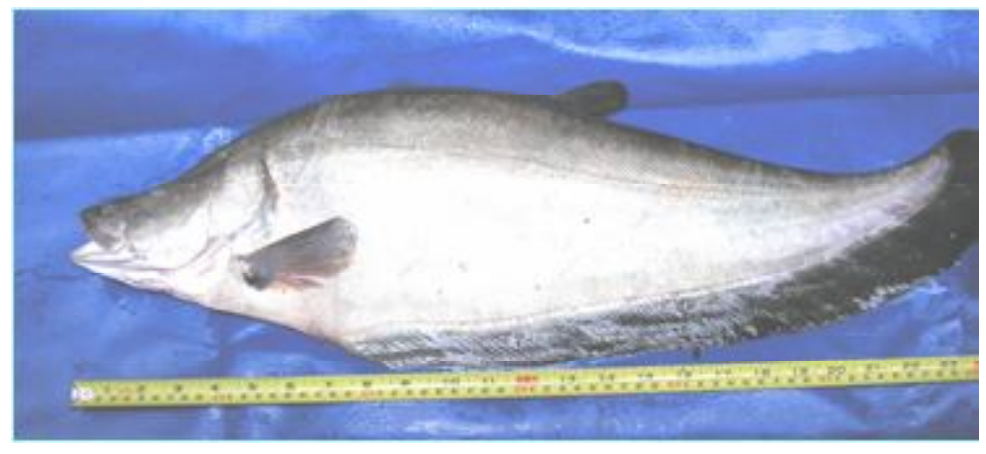

Gambar 1. Foto ikan belida (Notopterus chitala).

Untuk menghindari usaha penangkapan ikan belida secara berlebihan, maka harus ada pengaturan penangkapan, alat tangkap yang dioperasikan dan usaha perlindungan terhadap habitat ikan belida supaya dapat meningkatkan kesejahteraan petani atau nelayan. Tujuan tulisan ini memberikan informasi tentang aspek penangkapan ikan belida dengan alat tangkap tersebut.

\section{BAHAN DAN ALAT}

Alat tangkap jaring insang permukaan (floating gill net) untuk menangkap ikan belida merupakan alat tangkap ikan berbentuk empat persegi panjang terbuat dari benang nilon atau tali tangsi, ukuran mata jaring sama besar, panjang jauh lebih panjang dibanding dengan lebar, tali ris jaring bagian depan dan belakang dilengkapi dengan pelampung. Menurut Nomura (1985), jaring insang ada 4 bagian terdiri atas jaring permukaan (floating gill net), jaring dasar (bottom gill net), jaring melayang (drift gill net), dan jaring melingkar (surreunding gill net). Jaring insang permukaan untuk menangkap ikan belida tidak diberi pemberat. Alat tangkap tersebut dipasang 2 buah pelampung dari bambu diameter $3 \mathrm{~cm}$ pada bagian depan dan belakang supaya alat mengambang di atas permukaan air (Gambar 3).

Alat tangkap ikan belida yang dioperasikan oleh petani atau nelayan tergolong alat tangkap tradisional seperti lukah, pancing, jaring insang, teban, dan tajur. 

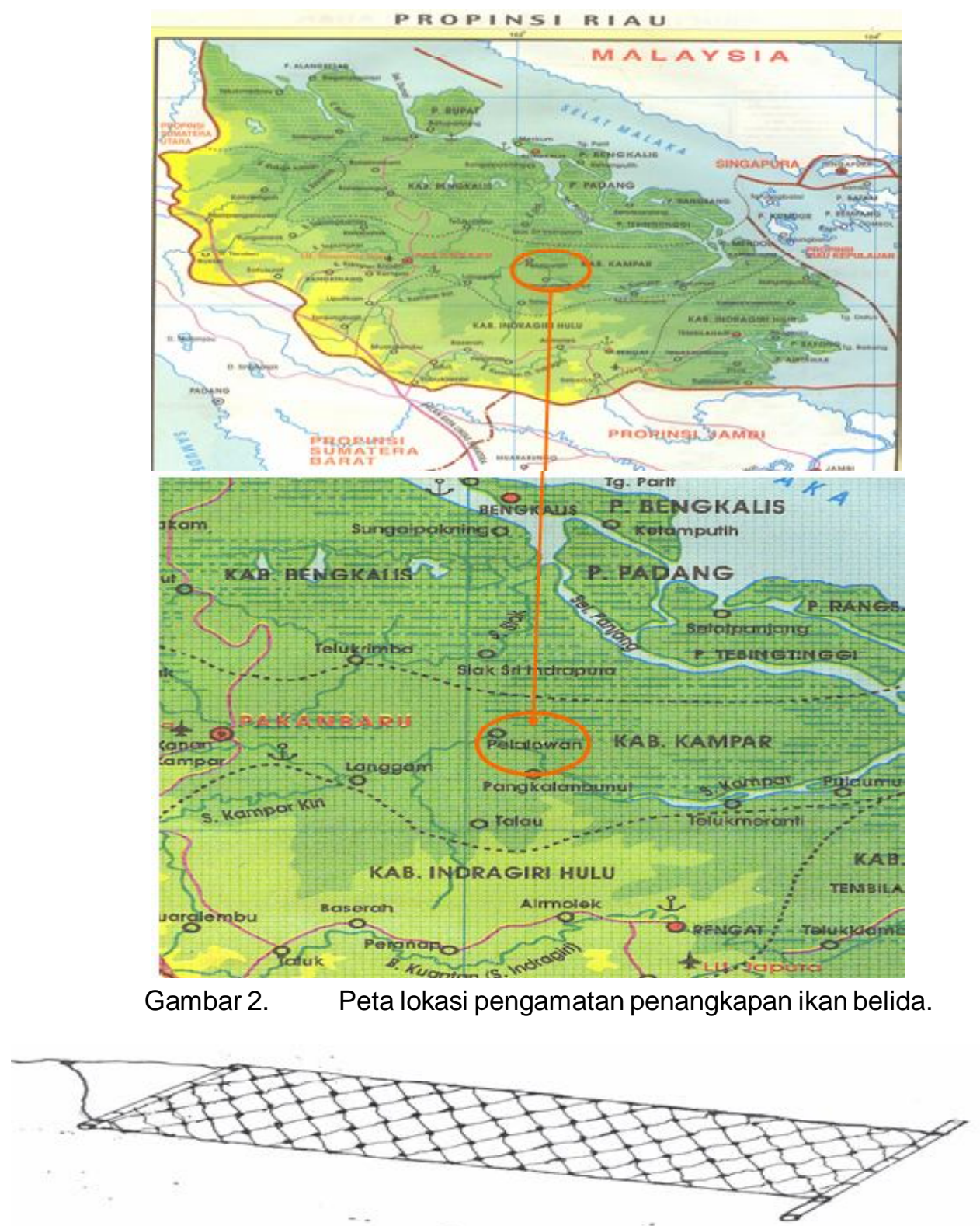

Gambar 3. Jaring insang permukaan alat tangkap ikan belida.

Bahan dan alat untuk pembuatan 1 unit alat tangkap jaring insang permukaan untuk menangkap ikan belida terdiri atas jaring insang No.16 ukuran mata jaring $15 \mathrm{~cm}$, tali ris kiri dan kanan No.100, tali penyulam No.10, dan pelampung bambu diameter 3 inci.

Alat terdiri atas gunting, cumban, dan pisau. Cara pembuatan alat tangkap jaring insang permukaan untuk penangkapan ikan belida di perairan Sungai Kampar, Propinsi Riau sebagai berikut jaring insang No.16 ukuran mata jaring $15 \mathrm{~cm}$ dibelah dan dipotong sesuai ukuran jaring yang akan dibuat. Benang nylon No.100 sebagai tali ris jaring disatukan pada jaring insang yang telah dipotong dan dibelah dijahit dengan benang nylon No.10 sehingga membentuk empat persegi panjang. Setelah jaring selesai dipasang tali ris, bagian ujung dan pangkal diberi pelampung bambu diamter $3 \mathrm{~cm}$ supaya jaring tidak tenggelam dari permukaan air.

Pengamatan teknik penangkapan ikan belida di Sungai Kampar bagian hilir, Propinsi Riau dilaksanakan dengan metode survei. Pengambilan contoh dilakukan 4 kali, yaitu musim penghujan (bulan September dan Nopember) dan musim kemarau (bulan Juni dan Agustus 2005). Alat tangkap yang digunakan adalah jaring insang permukaan dengan ukuran panjang $5 \mathrm{~m}$, lebar $2 \mathrm{~m}$, ukuran mata jaring $15 \mathrm{~cm}$ dilengkapi dengan dua buah pelampung dari bambu ukuran diameter 3 inci pada bagian hulu pelampung bambu berukuran panjang $2,10 \mathrm{~m}$, sedangkan bagian hilir berukuran $2,30 \mathrm{~m}$.

Alat tangkap jaring insang dioperasikan pada permukaan air searah dengan aliran sungai. Sebelum 
alat tangkap tersebut dioperasikan nelayan, terlebih dulu diadakan pengintaian tempat keberadaan ikan belida. Ikan belida akan naik ke atas permukaan air untuk menghirup udara dari atmosfir 2-3 kali. Setelah itu, baru alat tangkap gill net dioperasikan dengan cara membentangkan alat tangkap dari bagian hulu ke hilir. Tali pengikat alat tangkap bagian hulu diikatkan pada patok atau pohon kayu yang berada dipinggir tebing sungai supaya alat tersebut tidak hanyut terbawa arus air. Alat tangkap dioperasikan dipinggir tebing sungai dengan kedalaman 1,5-5 m. Habitat ikan belida berada di dasar sungai yang terdapat rantingranting kayu tempat ikan belida berlindung dan mencari makan. Ketika muncul di permukaan air untuk menghirup udara, maka ikan belida menabrak alat tangkap yang sedang dioperasikan. Pengoperasian alat tangkap ini pada sore hari setelah matahari terbenam, sedangkan hasil diambil pada pagi hari.

Hasil tangkapan di tampung di dalam tempat penampungan ikan berupa sangkar sebelum ikan tersebut dijual. Ikan yang mati disimpan dalam box dan diberi es supaya mutu ikan tetap segar. Hasil tangkapan diukur panjang bobot ditabulasikan dalam bentuk tabel dan dihitung rata-rata panjang $\mathrm{cm}$ bobot $\mathrm{kg} 1$ unit alat tangkap dalam 1 bulan.

\section{HASIL DAN BAHASAN}

Aktivitas penangkapan ikan belida di perairan Sungai Kampar bagian hilir. Hasil percobaan penangkapan tertera pada Tabel 1.

Tabel 1. Hasil tangkapan ikan belida dalam 1 bulan di Sungai Kampar bagian hilir di Kabupaten Kampar, Propinsi Riau

\begin{tabular}{clccc}
\hline No. & Kelompok & $\begin{array}{c}\text { Ukuran panjang } \\
(\mathbf{c m})\end{array}$ & $\begin{array}{c}\text { Bobot } \\
(\mathbf{k g})\end{array}$ & \multicolumn{1}{c}{ Keterangan } \\
\hline 1. & Induk & $65-75$ & 80 & 1 unit alat tangkap \\
2. & Dewasa & $34-65$ & 40 & \\
3. & Anakan & & - & \\
\hline & Jumlah & & $\mathbf{1 2 0}$ & \\
\hline
\end{tabular}

Produktivitas alat ini di Sungai Kampar bagian hilir tepat di Desa Pangkalan Kerinci, Kecamatan Pelalawan, Kabupaten Kampar, berkisar 5-10 kg/alat /malam. Ikan yang tertangkap berukuran $1-5 \mathrm{~kg} /$ ekor, tergolong induk dan dewasa.

Tabel 1 menujukkan bahwa hasil tangkapan ikan belida dengan memakai jaring insang permukaan dalam 1 bulan adalah ukuran induk dengan panjang rata-rata $65-75 \mathrm{~cm}$ dengan bobot $80 \mathrm{~kg}$, sedangkan anakan tidak tertangkap karena ukuran mata jaring yang dipergunakan khusus untuk menangkap ukuran induk dan dewasa.

\section{KESIMPULAN}

1. Hasil tangkapan terdiri atas ikan induk dan ikan dewasa dengan jumlah $120 \mathrm{~kg} / \mathrm{unit}$ alat/bulan.

2. Ikan yang tertangkap memakai alat tersebut berukuran induk dengan panjang $65-75 \mathrm{~cm}$ dan bobot $4-5 \mathrm{~kg}$, sedangkan ikan dewasa berukuran panjang $34-65 \mathrm{~cm}$ bobot $1-3,9 \mathrm{~kg}$.
3. Ikan belida kebanyakan tertangkap di Sungai Kampar bagian hilir, di Kabupaten Kampar, Propinsi Riau.

\section{DAFTAR PUSTAKA}

Anonimus. 2005. Statistik Perikanan. Dinas Kelautan dan Perikanan Daerah Tingkat I Riau. 60 pp.

Kottelat, A. M., J. A. Whitten, N. Kartikasari, \& Wiryoatmodjo. 1993. Fresh Water Fishes of Western Indonesia and Sulawesi. Jakarta. Indonesia. $221 \mathrm{pp}$.

Nomura, M. 1985. Fishing techniques. Japan International Corporation Agency. Tokyo. 108 pp. 